Announcements and Reports

1986 Conference of the Hegel Society of Great Britain

The Eighth Annual Conference of the HSGB was held at Pembroke College, Oxford on 11-13 September 1986. It was a joint conference of the HSGB and the Hegel-Archiv der Ruhr-Universityt, Bochum and its theme was 'History - Philosophy - Politics'. About 55 persons attended, of whom 15 came from Germany. Five papers were given by British and five by German participants, and each paper was formally commented on. The Conference's joint chairmen were Professors Raymond Plant and otto PBggeler; the joint organizing secretaries were Drs. Zbigniew Pelczynski and Hans-Christian Lucas. The financial support of the Fritz-Thyssen-stift and the British Academy made the international character of the September conference possible.

At the AGM of the HSGB, Professor H.S. Harris was elected Joint Honorary President of the Society. Z.A. Pelczynski was elected Chairman to fill the vacancy created by Professor W.H. Walsh's death; Stephen Houlgate was elected Secretary/Treasurer and became ex officio member of the HSGB Council. David Lamb and Sue Easton were elected to the Council following their resignation as Secretary/Treasurer and Associate Secretary/Treasurer. It was agreed to draw up a constitution for approval at the next AGM. The theme of the 1987 annual conference will be Hegel's philosophy of religion.

A full report on the 1986 Joint Conference will appear in issue no. 13 of the Bulletin.

In Memoriam W.H. Walsh

Editor's Note: W.H. Walsh, Professor Emeritus of the University of Edinburgh and Emeritus Fellow of Merton College, Oxford, President of the Hegel Society of Great Britain since September 1985 and member of its Council since the Society's formation, died in April 1986, aged 72. Characteristically, up to the last few days before his death, he was preoccupied with preparations for the Joint Conference of the HSGB and the Hegel-Archiv Bochum of which he had been elected Joint Chairman. The sad and unexpected death of this distinguished philosopher and Hegelian scholar is a tragic loss to British philosophy and to the HSGB and has deeply saddened the latter's members.

As a tribute to the man and the philosopher the Bulletin publishes two commemorative pieces. The Editor wishes to thank John Lucas for agreeing to the publication of his tribute in the Bulletin and John Llewelyn for writing his assessment of W.H. Walsh's philosophical position especially for the Bulletin.

Attention of the Bulletin's readers is also drawn to the obituary in The Times of 12 April 1986, and to the comprehensive bibliography of W.H. Waish's publications in Leon Pompa (ed.), Essays for W.H. Walsh (1981).

Substance and Form in History:

\title{
Richard Walsh
}

A tribute delivered in Merton Chapel on June 21st, 1986

It was Richard Walsh's fortune to be a philosopher at a time when the traditional concerns and approaches of philosophy were at a low ebb. He felt it as a misfortune. To be unfashionable as a philosopher is as hard as to be unpopular as a 
politician. To continue to ask questions dismissed as meaningless by the logical positivists or to discuss the nature of reality rather than the niceties of English usage was, when Richard began his career as a professional philosopher, to court courteous neglect at best and covert sneers at worst, and throughout his time at oxford Richard felt himself relegated to the margins of the oxford philosophical world. But although felt at the time as a misfortune, the fashions of the time can now be seen as a stroke of good fortune. It enabled Richard to develop his own thought with greater independence, and therefore greater longterm value, than if he had been in the swim of contemporary thinking, and it made his integrity more manifest than could have been the case had things been easier. The several strands of Richard's thought are all his own. Although they take account of the questions that were being asked in the second half of the twentieth century, they are unmistakably his thoughts and could never be regarded as merely standard-issue academic philosophy of that period. And in each case his courage in insisting on their importance was vindicated in his lifetime, and largely as a result of his own championing of them. Nor was his contribution only to the thought of his own generation. He wrote much and well. His works are not period pieces, and will not date as period pieces do.

Metaphysics was a term of abuse in the $1940 \mathrm{~s}$ and $50 \mathrm{~s}$. Metaphysical propositions were said to be pseudo-propositions and literally meaningless. Instead of accepting this and repeating it parrot fashion, or half-accepting it and trying to salvage a little from the wreck, Richard invited us to look at what the metaphysical philosophers had actually said, rather than dismiss them unread, and think through their thoughts, critically no doubt, but sympathetically too, and to judge them on their own merits, not according to some pre-judged formula. The result was his book Metaphysics, which not only made a difficult subject accessible to the ordinary reader, but forced many to rethink the slogans of the logical positivists and linguistic analysts and test them against the evidence of their own first-hand thought. It became implausible to go on using the word 'metaphysical' as a term of abuse; and although there were undoubtedly others who contributed to this change in the climate of philosophical opinion, the bibliographical evidence is strong for the leading part played by Richard in bringing it about.

The philosophy of history was in eclipse after the death of collingwood. Collingwood had said many shrewd things, but, though he continued to appeal to some, his style was not to the taste of the next generation and his work neglected, except by Richard and Isaiah Berlin, who appreciated what he, and behind him Dilthey and Vico, were trying to say, and who reformulated it in the idiom of their own time, and made philosophers take note. It was absurd that in oxford, where most philosophers had studied Ancient History as undergraduates, history, and the methods of historical thought, were little attended to and little understood. Richard's approach was, again, one of patient attention to the relevant material. He actually read works of history. Instead of deducing what history was from some theory of what it must be, he examined what historians wrote and the explanations they sought to give. He pointed out that received accounts of the philosophy of history failed to accommodate the facts of what historians actually did, and made the heretical suggestion that philosophers should attend to the practice of historians before telling them the principles of their craft.

Merton was known in my undergraduate days as a refuge of reactionary obscurantism where they studied Kant and Hegel, and did not know that these philosophers were no good and their writings just unintelligible waffle. It must have been a pleasing irony to Richard to see the philosophers who were dismissed as reactionary in his youth being hailed as avant garde by the left in the 1960s. Perhaps in this instance he had less influence on the tide of events, which flowed from distant climes; but his expressed conviction that Kant and Hegel were great philosophers who had something valuable to say to us was vindicated, and his courage and integrity in standing up for them made clear for all to see. To say what everyone else is saying is easy: to have spoken out against the current 
of contemporary opinion is a badge of courage that he had manifestly earned and could wear with pride.

I have spoken of Richard first as a thinker, for that is how he would have wished me to consider him. But he was also a man, a colleague, a teacher, a husband, father and friend. As a man he cared, sometimes passionately, about things, but more often his humanity was shown in his humour, a sly allusion in a tutorial, a philosophical joke to a grandchild worthy of Lewis Carroll. He was deeply altruistic. At the end of his life, when he knew that medicine could do no more for him, he volunteered for further tests on the way he was afflicted by paralysis, at the hands of a research team who found him a pecullarly interesting case; he felt he must contribute his cooperation for the sake of future sufferers. He was always a teacher, as a National Service man teaching miners' wives when to bath their babies, as a visiting professor in America showing the faculty by his own practice the importance of undergraduate teaching, in his last illness in hospital holding colloquies with nurses on the nature of philosophy. He loved Merton, and with good reason. Merton had, through its generous provision of awards, enabled boys without financial resources to come to oxford and make their way in the world. On one occasion the Bursar, discovering that Richard had spent all his money on books and was not eating proper meals, made him an 'honorary member of Hall' so that he could eat free. Throughout his life Richard identified with the scholarship boy, and sought to ensure that oxford should continue to exist for the sake of those who cared much for the things of the mind and were willing to forgo comfort and affluence in their pursuit of truth. He repaid the debt many-fold to Merton, not only in discharging the tedious and temperstraining chores of college office - especially as Senior Tutor, where the good he did for the college's tutorial performance is enjoyed by us still - but also' in the generous hospitality that he and Trixie dispensed, hour in and hour out, from their house in Merton Street, and pre-eminently in his own tutorial care for the young. As a tutor he was deeply concerned that his pupils should do well, but keenly aware, perhaps a reflection of his own sensitivity as a pupil, of the importance of fostering their independence and of the danger of impressing $h$ is own views on them to their detriment. Tutorials were centred on the pupil, not the tutor. He never belittled a young man's fumbling first attempts to philosophize, though a chance remark would make him realise a few weeks later that a catastrophic error had not escaped notice. His Greats training made him superb at analysing and laying out the problem an undergraduate was grappling with, while his understanding of Kant and Hegel made him, unlike many tutors of his generation, sensitive to the way the particular issue cohered with the whole philosophical scene, and adept at knitting the main ideas and arguments into an integrated whole. If an undergraduate was onto something, he would give him his head, and let him spend several weeks exploring a single topic, before bringing him back to questions likely to be set in Schools. Since it was only in public examinations conducted by others than himself that undergraduates could prove their mettle, he accepted it as his duty to prepare them to excel in the exercises that would be required of them rather than those he would have preferred to discuss with them. And in the same dispassionate spirit he later advised one, on his election to a fellowship, to study mathematical logic rather than Kant. But however reticent he was about his doctrines and scrupulous in not pushing his own opinions, he could not conceal his kindliness, his humour, his honesty, his sensitivity to argument, and his passionate concern for truth. Throughout his life his pupils caught more from him than he had consciously taught them, and his self-effacing humility won a deeper respect than argumentative assertiveness ever could.

Both in the early years of struggle at Merton and in those of fulfiiment at Edinburgh he showed the greatest sense of devotion in carrying out the obligations of his office. He had what, from his own point of view, was the misfortune of a sensitive conscience and a clear mind, and so constantly was being pressed to undertake time-consuming and mind-distracting chores, ending with his being in effect the Acting Vice-Chancellor of Edinburgh University. It is difficult to 
praise committees: we only notice when they do their work badly. Much of Richard's work as ar administrator in Edinburgh escaped notice: that is the sign of how well he did it.

As a teacher there his work was less easily forgotten. Although in the nature of the case known only to individuals, to those to whom it was known, it was often a decisive influence in their lives. Besides the patience, the care, the concern for pupils as people, what came through most strongly was a sense of intellectual honesty, the avoidance of the slick or fashionable answer, the concern for truth, the need to grapple and to try to understand fully what the question was and what the arguments were. In an age when some teachers of philosophy seemed to be academic opportunists, the total integrity of Richard Walsh was an inspiration. He was less constrained in Edinburgh than he was in oxford, and was able to put his own ideas into effect. He revolutionised the way philosophy was taught in the department; but once again he was concerned for philosophy as a whole, and greatly improved the teaching of logic as well as chose aspects that interested him personally. He was able to give the history of ('ilosophy full weight, insisting on the importance of first-hand acquaintance $v$ th the works of the masters, especially the Greeks, but above all of Kant. He wis a great Kant scholar, with a meticulous and masterly command of points of crtail, but illuminated throughout by his own independent critical judgement. He comtined, as any historian of philosophy must, knowledge with thought, and treated thinkers of past ages with respect but not with deference, seeking to understand what they said and why they said it, but always paying them the tribute of critical assessment, and being ready not merely to expound, but to evaluate, to criticize, and on occasion to disagree.

It was not only as a teacher and a writer that Richard made his contribution to the Republic of letters. In his later years of fulfilment and acclaim, he was generous in putting his time and prestige at the disposal of younger men making their way in the academic world. Himself a Kantian, he read Hegel sympathetically, although also critically, and was one of the few men of his generation prepared to take him seriously. His interest and encouragement meant much to a younger generation of thinkers trying to read Hegel with postanalytical eyes, needing the guidance that only Richard, who had traversed the same stony ground a quarter of a century earlier, could give. He became chairman of the Hegel Society of Great 8ritain, and in the last year of his life helped to organize an Anglo-German conference of Hegelian scholars. Hegelian studies owe much both to his early solitary endeavours in that field and to his later generous sociability towards those who joined him in the study of that master.

It is difficult, as we meet here to remember Richard Walsh and to give thanks for his life, to sum it up or make any simple assessment. Whatever I say, he was more than that. But we remember him as a man who chose a difficult rather than an easy path, and was rewarded in spending his intellectual life in the company of great minds rather than in trivial exercises. In as far as he was distracted, and he sometimes was, from pursuing the things of the mind, it was for moral reasons, out of concern for other people and the institutions he served, but never because he faltered in his concern for what was important, or sollght to trim his sails to the winds of fashion. He felt, as we all do, the temptations of the academic life, and suffered, in spite of the manifest success of his life and the esteem in which he was held, from a sense of failure engendered by his refusal to bow to the idols of his time. And in that refusal lies his greatest achievement, which we remember now, and shall continue to do, with the greatest gratitude.

John Lucas

Merton College, 0xford 